\title{
Exploration and Practice on Industry Association Participating in Applied Talents Training in Local Undergraduate Colleges and Universities

\author{
Liang $\mathrm{Li}^{1}$, Huiguang $\mathrm{Yin}^{1}$, Hui Jiang ${ }^{1}$, Liangfeng Dong ${ }^{1}$ \\ ${ }^{1}$ Xuzhou Institute of Technology, Xuzhou Jiangsu, 221018, China
}

Key Words: Industry Association, Local undergraduate colleges and universities, Applied talents training.

\begin{abstract}
This article first introduces the definition and function of Industry Association, analyzing the necessity of its participating in applied talents training in the local undergraduate colleges and universities. Then specifically describing the role of the Industry Association on the basis of the current market situation of our country. Finally, I have deep thinking on the future development of the industry association, and put forward my own suggestions from two aspects--the internal and external aspects, on how to improve the quality of applied talents training of the local undergraduate universities hoping to bring some reference value to colleges and universities, and realize the win-win cooperation situation.
\end{abstract}

\section{The necessity of industry association participating in applied talents training in the local undergraduate colleges and universities}

Industry association is a system field which has drawn extensive attention in the past 20 years. It plays an important role in the professional education of economic developed countries such as in Europe, the United States and Japan. According to "the Encyclopedia of American economics", industry association is defined as "an organization organized by some peers or businessmen voluntarily to achieve a common goal". In our country, with the gradual improvement of the market economy and the continuous deepening of the reform of administrative examination and approval system, industry association has been developed rapidly, the state-owned enterprises, private enterprises and foreign enterprises all actively participate in. Through the study of the main industry association role and function, I found that industry association is the industry intermediary organization between the government and enterprises. It should not only reprent the member enterprises and reflect the interests of the member enterprises, but also represent the administrative department for industry competent state administrative department and exercise part of the administrative management functions and powers. Thus, the nature and function of the industry association has determined its being one of the effective choices for applied talents training platform.

Agencies of the state council reform and function change program approved in 2013 clearly pointed out that: professional standards and evaluation standard formulated by department of the state council in accordance with laws shall be specifically identified by related industry association or academy[1]. Our country's education reform related scheme also affirmed the importance of the role of industry association in the university-enterprise cooperation and that businesses' participating in is the future development direction of colleges and universities[2]. So, industry association's participating in the applied talents training in colleges and universities also becomes the inevitable result of its development. 


\section{Problems in the local colleges and universities' cultivation of applied talents}

Under the background of rapid development of the national economic construction, how to develop applied talents adapted to the local economic development and meet the requirements of the industry is a common problem faced by the local undergraduate colleges and universities. To solve this problem, social practice must be based on, combined with the theory education, and industry-academy cooperation with industry enterprise is one of the effective ways. The actual process of cooperation, however, is not so easy as imagined. University-enterprise cooperation will have all kind of contradictions. In terms of the goal of talents training, local undergraduate colleges and universities focus on cultivating industry-need high-quality practical talents. So in the process of establishing the talent training scheme, demand for talent in the whole industry should be taken as a foothold. However, under One-on-one cooperation with enterprises mode, only part enterprises come into contact. So there are errors appearing between talents training and industry actual demand; in addition it is difficult to have deep development in industry-academy cooperation. Contact between university and industry enterprise mostly begins with the cooperation relations established between individual teachers and enterprises. This kind of cooperation are mostly cooperation between teachers' personal project and enterprises, with partnership relatively loose, lack of efficient management. Teachers themselves are hard to utilize the whole school resources for enterprise services. On the other hand, it is also difficult for them to feedback talent demand of the enterprise to the school. So it's difficult to maintain the partnership for a long time, while cooperation also hard to be developed into deeper level. For a long time, there is a shortage for enterprises' participating power, while enthusiasm not high, the phenomenon of "one-sided enthusiasm" formed. The contradiction of the warm attitude of school and cold attitude of enterprises has become the bottleneck of the deepen development of industry-academy cooperation in most local undergraduate colleges and universities. The loose cooperation cannot fundamentally realize the objective of talents training in local undergraduate colleges and universities and solve the industry's demand for applied talents. Therefore, local undergraduate colleges and universities urgently need a middle hub which can widely understand enterprise's demand of choosing and employing talents as well as contact with enterprise. In this way, talent training programs can be scientifically formulated and real applied talents cultivated.

\section{The practice of Industry Association participating in applied talents training in local undergraduate colleges and universities}

During the process of applied talents training in local undergraduate colleges and universities, Industry Association has played a role of communication hub between colleges and universities and industry enterprises. It has changed the "one-to-one" communion model between universities and enterprises in the past, provided both sides with a broader and more in-depth cooperation opportunity and foundation.On the one hand, through the communication with member companies, it can real-timely grasp the enterprise's demand and use situation of talents and understand enterprise's special requirements on scientific research, personnel continuing education etc. and provide service for industry member enterprises; On the other hand, Industry association has established an equal cooperation relation with universities, able to transger the talent demand of the whole industry in the region in a timely manner. Besides, it can use the resources of colleges and universities to provide technical services for the enterprises. Through the Industry association's function as a bridge, colleges and universities can fully understand the talent demand in a timely manner, concentrate on doing a good job of applied talents training so that meet the talent demand of industry member enterprises. It also can widen the cooperation form between universities and enterprises, make universities and enterprises conduct scientific research together to improve the capacity of university's serving local economic construction at the same time.

In recent years, in the practice exploration of applied talents training mode in the local undergraduate colleges and universities, under the guidance of the thought of running school--"facing 
the first tier, serving the local", through the tight cooperation with Industry Association, the school I work at has mplemented the innovation of talented person training mode. "Relying on industry, industry-university-research cooperation" is the guiding ideology of our school's personnel training mode. Through the bridge function of industry association, our school has realized an effective communication with industry enterprises. Under this mode, industry enterprises have completed the personnel training work with colleges and universities together. This has fundamentally guaranteed the quality of the applied talents in colleges and universities and at the same time promoted the technology development and progress of the industry enterprises, largely improving the enthusiasm of industry enterprises' participating in talents training in colleges and universities, forming a good mutual win-win situation among school, industry enterprises and society.

\section{Close to the industry development, industry association participates in the professional construction of colleges and universities.}

With the increasing acceleration of our country's industrialization and urbanization process, rapid development of construction industry, but because part of the staff has a weak awareness of production safety, in recent years, there are multiple building safety accidents appearing in our country, the serious lack of special safety management personnel in construction companies has restricted the development of building industry. The production safety problems in construction companies has also gradually got the attention from inside and outside the industry.

For this phenomenon, our college carried out in-depth cooperation with Construction safety and equipment management association of Jiangsu province(Hereinafter referred to as "Safety association". Taking use of its own resources, safety association has invited the responsible persons with premium quality in both the industry and enterprises, well-known experts and professors in colleges and universities in the province to discuss the construction safety problems and construction safety professional construction time and time again. They affirmed our college's idea of bid for the construction safety related major in the seminar, thinking that construction safety management related personnel training has the actual practical significance, that is, it can effectively fill the construction safety management talents gap at the present stage in China. Under the support of leadership of the school and industry departments at all levels, our college declared the "safety engineering" major and be approved. Facts have proved the correctness of this decision, since our school in 2007 set up the construction safety technology and management major for the first time, every year graduates of the major are in short supply.

\section{The universities and association's jointly making personnel cultivating program makes the university management more scientific.}

During the cooperation between the university I work at with Construction safety and equipment management association of Jiangsu province, in order to constantly optimize the construction safety professional talents training program and carry out high quality applied talents, under the push of safety association, our university has organized the experts, administrative officers in industry and enterprises to deeply participate in and set up the safety engineering professional teaching steering committee. Through the cooperation between universities and association, we have formulated professional cultivation objectives and standards and constructed course system as well as innovated teaching content; We have improved teaching conditions, increased teachers to promote the reform of personnel training mode. Besides, the advanced enterprises culture, professionalism and production technology have been integrated into all links of education teaching. Promoting education of cooperation between universities and enterprises to really produce applicable talents with high qualities developed in an all-around way as well as conform to the enterprise needs.

Based on the good results of cooperation between universities and association, Safety association paid \$1 million in our college in 2011 to set up "fraternity construction safety scholarship". This approach has effectively mobilized the enthusiasm and initiative of the students. From another perspective, it has also promoted the related professional talents cultivation from a certain level. Up to 
present, according to research, the industry association will set up scholarship for some major separately in colleges and universities, this action is the first time.

\section{Constructing practice base together to enhance students' practical innovation ability and improve the training quality of applied talents.}

In recent years, with the improvement of the prestige of the school I work at as well as the influence of the college I work at in provincial construction industry, with the help of several industry associations, our school has successively carried out the production-study-research cooperation with nearly hundred well-known industry enterprises such as Jiangsu construction engineering group co., LTD, Nantong Huaxin construction group and Suzhou gold mantis building decoration co., LTD etc. and established the practice base to exercise the engineering practice ability of students to enhance their ability to analyze and solve practical problems. In the process of practice, enterprises can also investigate the student in advance, directly employing the excellent students. This can save many of the intermediate links during companies' recruitment of talented person, greatly stimulated the enthusiasm of business cooperation.

In 2011, our college built the construction safety and security laboratory together with Safety Association. College, Safety Association and enterprises assume different roles so as to realize platform sharing through the way of building laboratory together. There are both policy support and guidance of the association, technical support of colleges and universities, and the in-depth participation of the construction enterprises. It can not only provide students with real environment and conditions for engineering practice, but also devote to the scientific research and experiment and simulation in the field of civil engineering, cooperate with enterprises to carry out applied research and technology development, all these are of great significance for the enterprise's technology innovation and long-term development. The enterprises participating in colleges and universities' talents training mode is a performance of the depth and breadth of industry-academy cooperation education going towards a higher level, making the practice teaching of colleges and universities more close to the local industry development needs, played a very good effect for the improvement of applied talents training, strengthening the students' practice innovation ability and employment ability as well as the construction industry enterprises technical innovation, implementing a win-win situation between schools, associations, enterprises and students.

The association building a bridge to broaden the channels of university students' employment, improving the quality of university students' employment

The talents trained by local undergraduate colleges and universities are applied talents facing grass roots and first tier. Graduates' employment quality and post compatibility are important standards to measure the quality of personnel training. Employment quality depends on whether talents' ability, quality are in line with the industry needs and social development needs. The local undergraduate colleges and universities on the one hand should accomplish college students' employment guidance work to guide the student to set up correct employment attitude and professional view. On the other hand, broaden the employment channels to achieve high quality employment based on the platform of industry association.

Conducting education training mode reform, exploring the customised talent mode. Colleges and universities can carry out university-enterprise cooperation customised personnel training with industry enterprises and targetedly carry out talents training according to the demands of enterprises through the platform built by the industry association. This requires colleges and universities to realize the importance of teaching reform in the process of talent cultivation, that is, taking enterprise demand as the starting point, training high quality talents as the final goal. Only in this way can we fundamentally improve the talents' core competitiveness in the enterprise.

Holding special job fairs with the power of industry association. The universities can cooperate with industry enterprises through introduction of industry enterprises through industry association by way of special job fairs. This can not only be beneficial to the students, creating enough jobs for them, but also play a positive role for the relation between college and enterprise. 
Taking use of the platform advantage of industry association to widen the information exchange channel of the graduates. Using the network platform of industry association to release graduates information of cooperated colleges and universities, and recommend outstanding graduates to industry enterprises. This can expand the employment service of college graduates and provide an efficient platform for college students' employment and industry enterprises' recruitment.

\section{Using platform of industry association to strengthen the construction of double-teaching troops}

Building bridge by industry association to construct university-enterprise cooperation platform. The three parties determine the teacher practice exercise plan, steps and concrete content through joint consultation to strengthen the practice of the college teachers' exercise together and share each other's software and hardware resources. The implementation effect of practice exercise project can be evaluated by the industry association.

\section{Conclusion and suggestions}

After years of practice, we found that the industry association participating in the applied talents training in local undergraduate colleges and universities is a demand social economic development puts forward for the industry association in the new period, a necessity of its development. A bridge is constructed between universities and enterprises through the industry association to make it possible to guide the university-enterprise cooperation to be developed into a more efficient and pragmatic direction. This has important significance on the applied talent training in local undergraduate colleges and universities. In addition, the innovative talent cultivation mode has a very good role in promoting the acceleration of the development of industry enterprises. It can be said to be a win-win choice.We suggest that the government increase support and motivation on industry association's participating in the universities' talents training on policy to let industry association actively participate in the universities' especially the local undergraduate colleges and universities' applied talents training, let Industry Association under the guidance of our government, on the one hand, establish and perfect the guarantee mechanism, clear the responsibilities and rights of the three sides in the cooperation, form the long-term mechanism of cooperation through the universities-enterprises cooperation platform; On the other hand, set up sound cooperation quality monitoring system, strengthen parties' information exchange on the cooperation platform, scientific and reasonable evaluation on the development of cooperation to promote the further development of industry-university-research cooperation.

\section{References}

[1] 12th National People's Congress Kick-off Meeting Decision about the institution reform and function transformation scheme of the state council, 2013-05-01.

[2] The ministry of education, The national medium and long-term plan for education reform and development(2010-2020), China's ministry of education website, 2010-07-29. 